\title{
The clinical impact of MTHFR polymorphism on the vascular complications of sickle cell disease
}

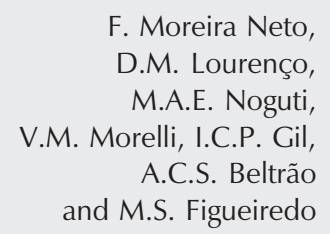

F. Moreira Neto,

D.M. Lourenço,

M.A.E. Noguti,

V.M. Morelli, I.C.P. Gil,

A.C.S. Beltrão

and M.S. Figueiredo

\author{
Disciplina de Hematologia e Hemoterapia, Escola Paulista de Medicina, \\ Universidade Federal de São Paulo, São Paulo, SP, Brasil
}

\section{Correspondence \\ M.S. Figueiredo \\ Disciplina de Hematologia \\ e Hemoterapia, EPM, UNIFESP \\ Rua Botucatu, 740, 3o andar \\ 04023-900 São Paulo, SP \\ Brasil \\ Fax: +55-11-5571-8806 \\ E-mail: stella@hemato.epm.br}

Publication supported by FAPESP.

Received September 23, 2005

Accepted June 20, 2006

\section{Abstract}

Sickle cell disease (SCD) is one of the most common inherited diseases in the world and the patients present notorious clinical heterogeneity. It is known that patients with SCD present activation of the blood coagulation and fibrinolytic systems, especially during vaso-occlusive crises, but also during the steady state of the disease. We determined if the presence of the factor $\mathrm{V}$ gene G1691A mutation (factor V Leiden), the prothrombin gene G20210A variant, and methylenetetrahydrofolate reductase (MTHFR) C677T polymorphism may be risk factors for vascular complications in individuals with SCD. We studied 53 patients with SCD (60\% being women), 29 with SS (sickle cell anemia; 28 years, range: 13-52 years) and 24 with SC (sicklehemoglobin $\mathrm{C}$ disease; 38.5 years, range: $17-72$ years) hemoglobinopathy. Factor V Leiden, MTHFR C677T polymorphism, and prothrombin G20210A variant were identified by PCR followed by further digestion of the PCR product with specific endonucleases. The following vascular complications were recorded: stroke, retinopathy, acute thoracic syndrome, and X-ray-documented avascular necrosis. Only one patient was heterozygous for factor V Leiden (1.8\%) and there was no prothrombin G20210A variant. MTHFR 677TT polymorphism was detected in 1 patient (1.8\%) and the heterozygous form 677TC was observed in 18 patients (34\%, 9 with SS and 9 with SC disease), a prevalence similar to that reported by others. No association was detected between the presence of the MTHFR 677T allele and other genetic modulation factors, such as $\alpha$-thalassemia, $\beta$-globin gene haplotype and fetal hemoglobin. The presence of the MTHFR $677 \mathrm{~T}$ allele was associated with the occurrence of vascular complications in SCD, although this association was not significant when each complication was considered separately. In conclusion, MTHFR C677T polymorphism might be a risk factor for vascular complications in SCD.
Key words - Sickle cell disease

- SC hemoglobinopathy

- Sickle hemoglobinopathies

- Inherited hypercoagulation states

- MTHFR polymorphism 


\section{Introduction}

Sickle cell disease (SCD) is one of the most common inherited diseases in the world. In Brazil, 700 to 1000 infants with SCD are estimated to be born each year (1). Even with the same inherited DNA mutation within the $\beta$-globin gene, patients present a notorious clinical heterogeneity. Additional genetic factors such as $\alpha$-thalassemia, fetal hemoglobin synthesis, and B-globin haplotype have been identified, but none of these can fully explain the differences in clinical expression observed in these patients. Probably, there are other elements that contribute to the many phenotypes of the disease (2-5).

It has been known for a long time that patients with SCD show activation of the blood coagulation and fibrinolytic systems, as well as increased platelet activity and consumption of coagulation inhibitors, especially during vaso-occlusive crises, but also during the steady state of the disease (69). Vascular complications are an important and perplexing aspect of the clinical spectrum of sickle cell anemia, although there is controversial evidence surrounding the role of thrombosis in this complication $(10,11)$. Because of the importance of vascular complications in the pathophysiology of SCD, a number of genetic polymorphisms associated with thrombophilia have been studied as potential genetic modifiers of SCD.

In the present study, we investigated the hypothesis that the presence of the factor $\mathrm{V}$ gene G1691A mutation (factor V Leiden), the prothrombin gene G20210A variant, and MTHFR (methylenetetrahydrofolate reductase) C677T polymorphism may be a risk factor for vascular complications in individuals with SS and SCD.

\section{Patients and Methods}

We evaluated 53 patients of African descent with SCD, 29 with SS (sickle cell anemia) and 24 with SC (sickle-hemoglobin
C disease) hemoglobinopathy. The study population consisted of 32 women and 21 men. The following vascular complications were identified: stroke by focal neurologic deficit and computed tomography, retinopathy by ophthalmoscopic fundus examination, acute thoracic syndrome by clinical and radiological findings, and avascular necrosis (AVN) of femoral or humeral heads by X-rays. All patients, including those with vascular complications, were on oral folate administration ( $5 \mathrm{mg} /$ day).

The study was approved by the local Ethics Committee on human research. After written informed consent was obtained, approximately $5 \mathrm{~mL}$ whole blood was collected in EDTA and stored at $-4^{\circ} \mathrm{C}$ until DNA extraction. Factor V Leiden mutation, MTHFR C677T polymorphism, and prothrombin G20210A variant were identified by PCR followed by further digestion of the PCR product with specific endonucleases, as described in Refs. 12-14.

The significance of the difference between medians was determined by the Mann-Whitney U-test. Fisher's exact test was used to compare the frequency of observations in contingency tables. Odds ratios (OR), as an estimate of relative risk, and $95 \%$ confidence intervals $(95 \% \mathrm{CI})$ were calculated using standard methods. A two-tailed $\mathrm{P}<0.05$ value was considered to be statistically significant. Statistical tests were performed using the Instat2 software (GraphPad, San Diego, CA, USA).

\section{Results}

Median age was lower for SS patients (28 years, range: 13 to 52 years) than for SC patients (38.5 years, range: 17 to 72 years), with the difference being almost statistically significant $(P=0.059)$. Median hemoglobin level was lower for SS patients $(7.95 \mathrm{~g} / \mathrm{dL})$ than for SC patients $(11.53 \mathrm{~g} /$ $\mathrm{dL}$ ), whereas fetal hemoglobin level was higher for SS patients $(6.2 \%)$ than for SC patients $(2.1 \%)$. These differences were both 
significant $(\mathrm{P}<0.001)$.

The vascular complications investigated in the present study were more frequent in SC patients $(83.3 \%)$ than in SS patients (34.5\%), as shown in Table 1. Retinopathy was significantly more frequent in SC patients, as expected, whereas acute thoracic syndrome was only recorded among SS patients (Table 1).

Only one patient was heterozygous for the factor $\mathrm{V}$ Leiden mutation $(1.8 \%)$ and there was no prothrombin G20210A mutation. Because of the low frequency observed, the relationship between these mutations and other epistatic factor was not considered further.

MTHFR 677TT polymorphism was detected in 1 patient $(1.8 \%)$ and the heterozygous form 677TC was observed in 18 patients (34\%), 9 with SS and 9 with SC disease. No association was detected when we compared the presence of the MTHFR 677T allele and other genetic modulation factors such as $\alpha$-thalassemia, $\beta$-globin gene haplotype and fetal hemoglobin.

The presence of the MTHFR 677T allele was associated with the occurrence of vascular complications in SCD, although this association was not significant if each complication is considered separately (Table 2). Taking all 4 complications together, the OR was 4.8 (95\% CI: $1.3-17.3, \mathrm{P}=0.020)$. The association was still significant when we considered stroke, retinopathy and AVN, with an OR of 3.5 (95\% CI: $1.1-11.5, \mathrm{P}=$ 0.047).

\section{Discussion}

Although $\mathrm{HbS}$ cells are indispensable for the generation of the disease, several other phenomena, affected by a multitude of genes other than the one directly mutated (epistatic effect), play an important role (15). The importance of thrombosis in the pathophysiology of SCD has been recently recognized. Considerable evidence suggests that endo-
Table 1. Prevalence of stroke, avascular necrosis (AVN), retinopathy, and acute thoracic syndrome (ATS) in patients with sickle cell disease (SCD).

\begin{tabular}{lccc}
\hline & $\begin{array}{c}\text { SCD patients } \\
(\mathrm{N}=53)\end{array}$ & $\begin{array}{c}\text { SS patients } \\
(\mathrm{N}=29)\end{array}$ & $\begin{array}{c}\text { SC patients } \\
(\mathrm{N}=24)\end{array}$ \\
\hline Cases with vascular complication & $30(56.6 \%)$ & $10(34.5 \%)$ & $20(83.3 \%)^{*}$ \\
$\quad$ Stroke & $1(1.8 \%)$ & $1(3.4 \%)$ & $0(0.0 \%)$ \\
AVN & $2(3.8 \%)$ & $1(3.4 \%)$ & $1(4.2 \%)$ \\
Retinopathy & $16(30.1 \%)$ & $1(3.4 \%)$ & $15(62.5)$ \\
ATS & $4(7.5 \%)$ & $4(13.8 \%)$ & $0(0.0 \%)$ \\
Combined complications ${ }^{\#}$ & $7(13.2 \%)$ & $3(10.3 \%)$ & $4(16.7 \%)$ \\
Episodes of vascular complication & & & \\
Stroke & $3(5.6 \%)$ & $3(10.3 \%)$ & $0(0 \%)$ \\
AVN & $8(15.1 \%)$ & $3(10.3 \%)$ & $5(20.8 \%)$ \\
Retinopathy & $21(39.6 \%)$ & $2(6.9 \%)$ & $19(79.2 \%)^{*}$ \\
ATS & $6(11.3 \%)$ & $6(20.7 \%)$ & $0(0 \%)^{*}$ \\
\end{tabular}

$\mathrm{SS}=$ sickle cell anemia; $\mathrm{SC}=$ sickle-hemoglobin $\mathrm{C}$ disease .

\#4 patients had AVN + retinopathy; 1 patient had stroke + AVN; 1 patient had stroke + ATS; 1 patient had AVN + retinopathy + ATS.

${ }^{*} \mathrm{P}<0.05$ compared to SS (Fisher's exact test).

Table 2. Odds ratio for the association between the 677T allele and vascular complications in sickle cell disease.

\begin{tabular}{|c|c|c|c|c|}
\hline MTHFR & \multicolumn{2}{|c|}{ Vascular complication } & \multirow{2}{*}{$\begin{array}{c}\text { Odds ratio } \\
1^{\#}\end{array}$} & \multirow[t]{2}{*}{$95 \% \mathrm{Cl}$} \\
\hline CC & $\begin{array}{c}\mathrm{AVN}+ \\
3\end{array}$ & $\begin{array}{c}\text { AVN - } \\
31\end{array}$ & & \\
\hline $\mathrm{CT} / \mathrm{TT}$ & 5 & 14 & 3.7 & $0.8-17.7$ \\
\hline & $\mathrm{R}+$ & $\mathrm{R}-$ & & \\
\hline $\mathrm{CC}$ & 11 & 23 & $1^{\#}$ & \\
\hline $\mathrm{CT} / \mathrm{TT}$ & 10 & 9 & 2.3 & $0.7-7.4$ \\
\hline $\mathrm{CC}$ & $\begin{array}{c}\text { ATS + } \\
3\end{array}$ & $\begin{array}{c}\text { ATS - } \\
31\end{array}$ & $1^{\#}$ & \\
\hline $\mathrm{CT} / \mathrm{TT}$ & 3 & 16 & 1.9 & $0.4-10.7$ \\
\hline $\mathrm{CC}$ & $\begin{array}{c}\text { Stroke }+ \\
2\end{array}$ & $\begin{array}{c}\text { Stroke - } \\
\quad 32\end{array}$ & $1^{\#}$ & \\
\hline $\mathrm{CT} / \mathrm{TT}$ & 1 & 18 & 0.9 & $0.08-10.5$ \\
\hline & AVN + R + stroke & No $A V N, R$ or stroke & & \\
\hline $\mathrm{CC}$ & 13 & 21 & $1^{\#}$ & \\
\hline $\mathrm{CT} / \mathrm{TT}$ & 13 & $6^{*}$ & 3.5 & $1.1-11.5$ \\
\hline & $\mathrm{AVN}+\mathrm{R}+$ stroke $+\mathrm{ATS}$ & No vascular complication & & \\
\hline $\mathrm{CC}$ & 15 & 19 & $1^{\#}$ & \\
\hline $\mathrm{CT} / \mathrm{TT}$ & 15 & $4^{*}$ & 4.8 & $1.3-17.3$ \\
\hline
\end{tabular}

AVN = avascular necrosis; $\mathrm{R}=$ retinopathy; $\mathrm{ATS}=$ acute thoracic syndrome.

\#Reference risk factor. ${ }^{*} P<0.05$ for comparison between patients with and without vascular complication with regard to the distribution of the allele 677T (Fisher's exact test). 
thelial damage and thrombosis play important contributory roles in the vaso-occlusive complications of SCD $(10,16)$.

We found only 1 patient in $53 \mathrm{SS}+\mathrm{SC}$ subjects heterozygous for factor $\mathrm{V}$ Leiden and no patient with prothrombin mutation, as expected, since these polymorphisms are more frequent in Caucasians.

The MTHFR 677TT genotype was detected in $1.8 \%$ of SCD patients, which is similar to the prevalence reported by others, ranging from 1 to $2.8 \%$ (17-20). Balasa et al. (18) found a prevalence of $1 \%$ for this genotype among 110 normal American Blacks, whereas its prevalence among Caucasians ranges from 10 to $20 \%$, depending on the geographic distribution (21-26). In Brazil, despite the great miscegenation, there seems to be a high proportion of Caucasians within normal individuals, since Morelli et al. (27) reported a $9 \%$ prevalence of $677 \mathrm{TT}$ and Franco et al. (28) found a $16.6 \%$ prevalence.

We found that the $677 \mathrm{~T}$ allele was associated with vaso-occlusive complications in patients with SCD. Some investigators did not find an association between MTHFR C677T and clinical manifestations in SCD: Cumming et al. (17) evaluated stroke in SS patients and Zimmerman et al. (19) evaluated the occurrence of stroke and AVN in $\mathrm{SS}, \mathrm{SC}$ and $\mathrm{S}^{0}$ thalassemia patients. In a Brazilian study conducted on 73 patients with sickle cell anemia, SC hemoglobinopathy and $\mathrm{S}^{0}$ thalassemia, none presented homozygosity for the MTHFR 677T allele, including those with vascular complications such as stroke or deep vein thrombosis (29).
On the other hand, Kutlar et al. (30) found a significant association between the 677T allele and AVN in SS patients, which has also been reported in individuals without SCD (31).

Hyperhomocystinemia is a significant risk factor for venous thrombosis in patients without known acquired thrombophilia or other genetic risk factors for venous thrombosis, underscoring the importance of homocysteine evaluation in thrombotic disease (27). The role of moderate hyperhomocystinemia as a cause of stroke in adults has been well documented, and it has been suggested that high homocysteine levels may be a risk factor for the development of stroke in patients with SCD as well (32). Morelli et al. (27) found that homocystinemia levels are significantly higher in homozygotes for the MTHFR C677T mutation both in patients with venous thromboembolism and controls.

Chronic ongoing hemolysis in sickle cell patients causes a high demand for folate, necessary for normal erythropoiesis. The presence of the $677 \mathrm{~T}$ allele, which is associated with high homocysteine levels, may aggravate the effect of this amino acid on the vascular system. Actually, Houston et al. (33) showed a clear influence of hyperhomocystinemia on the risk of stroke in SS patients, although their folate status was normal.

In conclusion, our data suggest that MTHFR C677T polymorphism might be a risk factor for vascular complications in SCD, probably contributing to the deleterious effect of hyperhomocystinemia caused by folate imbalance.

\section{References}

1. Lyra IM, Goncalves MS, Braga JA, Gesteira MF, Carvalho MH, Saad ST, et al. Clinical, hematological, and molecular characterization of sickle cell anemia pediatric patients from two different cities in Brazil. Cad Saude Publica 2005; 21: 1287-1290.

2. Steinberg MH, Rosenstock W, Coleman MB, Adams JG, Platica O, Cedeno $\mathrm{M}$, et al. Effects of thalassemia and microcytosis on the hematologic and vasoocclusive severity of sickle cell anemia. Blood
1984; 63: 1353-1360.

3. Powards DR. $\beta^{S}$ Gene cluster haplotypes in sickle cell anemia. Clinical and hematologic features. Hematol Oncol Clin North Am 1991; 5: 475-493.

4. Rieder RF, Safaya S, Gillette P, Fryd S, Hsu H, Adams JG III, et al. Effect of beta-globin gene cluster haplotype on the hematological and clinical features of sickle cell anemia. Am J Hematol 1991; 36 : 
184-189.

5. Figueiredo MS, Kerbauy J, Goncalves MS, Arruda VR, Saad ST, Sonati MF, et al. Effect of alpha-thalassemia and beta-globin gene cluster haplotypes on the hematological and clinical features of sickle-cell anemia in Brazil. Am J Hematol 1996; 53: 72-76.

6. Lourenço D, Sampaio MU, Kerbauy J, Sampaio CA. Estimation of plasma kallikrein in sickle-cell anemia, and its relation to the coagulation and fibrinolytic systems. Adv Exp Med Biol 1989; 247B: 553557.

7. Peters M, Plaat BE, ten Cate H, Wolters HJ, Weening RS, Brandjes DP. Enhanced thrombin generation in children with sickle cell disease. Thromb Haemost 1994; 71: 169-172.

8. Key NS, Slungaard A, Dandelet L, Nelson SC, Moertel C, Styles LA, et al. Whole blood tissue factor procoagulant activity is elevated in patients with sickle cell disease. Blood 1998; 91: 4216-4223.

9. Bayazit AK, Kilinc Y. Natural coagulation inhibitors (protein C, protein $S$, antithrombin) in patients with sickle cell anemia in a steady state. Pediatr Int 2001; 43: 592-596.

10. Setty BN, Rao AK, Stuart MJ. Thrombophilia in sickle cell disease: the red cell connection. Blood 2001; 98: 3228-3233.

11. Hebbel RP. Thrombogenesis or thrombogenic risk? J Lab Clin Med 2001; 137: 381-382.

12. Arruda VR, Annichino-Bizzacchi JM, Costa FF, Reitsma PH. Factor $\mathrm{V}$ Leiden (FVQ 506) is common in a Brazilian population. $A m \mathrm{~J}$ Hematol 1995; 49: 242-243.

13. Frosst $P$, Blom HJ, Milos R, Goyette $P$, Sheppard CA, Matthews RG, et al. A candidate genetic risk factor for vascular disease: a common mutation in methylenetetrahydrofolate reductase. Nat Genet 1995; 10: 111-113.

14. Poort SR, Rosendaal FR, Reitsma PH, Bertina RM. A common genetic variation in the 3 '-untranslated region of the prothrombin gene is associated with elevated plasma prothrombin levels and an increase in venous thrombosis. Blood 1996; 88: 3698-3703.

15. Nagel RL. Severity, pathobiology, epistatic effects, and genetic markers in sickle cell anemia. Semin Hematol 1991; 28: 180-201.

16. Belhassen L, Pelle G, Sediame S, Bachir D, Carville C, Bucherer C, et al. Endothelial dysfunction in patients with sickle cell disease is related to selective impairment of shear stress-mediated vasodilation. Blood 2001; 97: 1584-1589.

17. Cumming AM, Olujohungbe A, Keeney S, Singh H, Hay CR, Serjeant GR. The methylenetetrahydrofolate reductase gene C677T polymorphism in patients with homozygous sickle cell disease and stroke. Br J Haematol 1999; 107: 569-571.

18. Balasa VV, Kalinyak KA, Bean JA, Stroop D, Gruppo RA. Hyperhomocysteinemia is associated with low plasma pyridoxine levels in children with sickle cell disease. J Pediatr Hematol Oncol 2002; 24: 374-379.

19. Zimmerman SA, Ware RE. Inherited DNA mutations contributing to thrombotic complications in patients with sickle cell disease. Am J Hematol 1998; 59: 267-272.

20. Romana M, Muralitharan S, Ramasawmy R, Nagel RL, Krishnamoorthy $\mathrm{R}$. Thrombosis-associated gene variants in sickle cell anemia.
Thromb Haemost 2002; 87: 356-358.

21. Koch HG, Nabel P, Junker R, Auberger K, Schobess R, Homberger A, et al. The 677T genotype of the common MTHFR thermolabile variant and fasting homocysteine in childhood venous thrombosis. Eur J Pediatr 1999; 158 (Suppl 3): S113-S116.

22. Brown K, Luddington R, Baglin T. Effect of the MTHFRC677T variant on risk of venous thromboembolism: interaction with factor $\mathrm{V}$ Leiden and prothrombin (F2G20210A) mutations. Br J Haematol 1998; 103: $42-44$

23. Alhenc-Gelas M, Arnaud E, Nicaud V, Aubry ML, Fiessinger JN, Aiach $\mathrm{M}$, et al. Venous thromboembolic disease and the prothrombin, methylene tetrahydrofolate reductase and factor $\mathrm{V}$ genes. Thromb Haemost 1999; 81: 506-510.

24. Kluijtmans LA, den Heijer M, Reitsma PH, Heil SG, Blom HJ, Rosendaal FR. Thermolabile methylenetetrahydrofolate reductase and factor $\mathrm{V}$ Leiden in the risk of deep-vein thrombosis. Thromb Haemost 1998; 79: 254-258.

25. Margaglione M, D'Andrea G, d'Addedda M, Giuliani N, Cappucci G, lannaccone $\mathrm{L}$, et al. The methylenetetrahydrofolate reductase TT677 genotype is associated with venous thrombosis independently of the coexistence of the FV Leiden and the prothrombin A20210 mutation. Thromb Haemost 1998; 79: 907-911.

26. Salomon O, Steinberg DM, Zivelin A, Gitel S, Dardik R, Rosenberg $\mathrm{N}$, et al. Single and combined prothrombotic factors in patients with idiopathic venous thromboembolism: prevalence and risk assessment. Arterioscler Thromb Vasc Biol 1999; 19: 511-518.

27. Morelli VM, Lourenço DM, D’Almeida V, Franco RF, Miranda F, Zago MA, et al. Hyperhomocysteinemia increases the risk of venous thrombosis independent of the C677T mutation of the methylenetetrahydrofolate reductase gene in selected Brazilian patients. Blood Coagul Fibrinolysis 2002; 13: 271-275.

28. Franco RF, Reitsma PH, Lourenço D, Maffei FH, Morelli V, Tavella $\mathrm{MH}$, et al. Factor XIII Val34Leu is a genetic factor involved in the etiology of venous thrombosis. Thromb Haemost 1999; 81: 676-679.

29. Andrade FL, Annichino-Bizzacchi JM, Saad ST, Costa FF, Arruda VR. Prothrombin mutant, factor V Leiden, and thermolabile variant of methylenetetrahydrofolate reductase among patients with sickle cell disease in Brazil. Am J Hematol 1998; 59: 46-50.

30. Kutlar A, Kutlar F, Turker I, Tural C. The methylene tetrahydrofolate reductase (C677T) mutation as a potential risk factor for avascular necrosis in sickle cell disease. Hemoglobin 2001; 25: 213-217.

31. Zalavras CG, Malizos KN, Dokou E, Vartholomatos G. The 677C $\rightarrow T$ mutation of the methylene-tetrahydrofolate reductase gene in the pathogenesis of osteonecrosis of the femoral head. Haematologica 2002; 87: 111-112.

32. Jacques PF, Bostom AG, Williams RR, Ellison RC, Eckfeldt JH, Rosenberg $\mathrm{IH}$, et al. Relation between folate status, a common mutation in methylenetetrahydrofolate reductase, and plasma homocysteine concentrations. Circulation 1996; 93: 7-9.

33. Houston PE, Rana S, Sekhsaria S, Perlin E, Kim KS, Castro OL. Homocysteine in sickle cell disease: relationship to stroke. $A m \mathrm{~J}$ Med 1997; 103: 192-196. 